\section{CLIMATOLOGICAL OBSERVATIONS.}

VALUABLE instalment has been added to the long series of meteorological observations taken at the Radcliffe Observatory, Oxford, by the publication of a volume containing the results for the five years 1906-1910. In its main features the volume is arranged on the same lines as before, the principal exceptions being the omission of (I) the readings of the underground platinum-resistance thermometers, which will be dealt with in a separate paper, and (2) the results obtained from the photographic recording instruments, but the records are continued at present. The tables exhibit very clearly the mean daily, monthly, and annual results for the various elements. The wind velocity is deduced with the old factor 3 , but to reduce this to the new factor 2.2 it is only necessary to multiply the quantities by $0^{\circ} 733$. From a special table prepared by Dr. Rambaut for the thirty years I88I-I9I0, the mean yearly horizontal motion of the air is 108,000 miles; it shows an apparent periodic annual variation, with an amplitude of about 3.8 miles an hour, the maximum occurring in March and the minimum in September.

The report recently issued by the Survey Department of Egypt upon the rains of the Nile basin and the flood of rgto claims that the decade which has just passed ranks as the most important in the study of the Nile from the hydrographical and meteorological points of view. The investigations during that period are chiefly due to the instigation and personal efforts of Sir W. Garstin and to the discussion of his data by various men of science. Among the principal results of this work are:-(I) A proper appreciation of the enormous loss of water in marshy regions. (2) The regulating effect of the trough wherever a rapid tributary joins a more sluggish one. (3) A more precise knowledge of the relative parts played by the different tributaries. (4) The importance of the contribution returned to the river from underground sources. During rgio there was a general or partial failure of rain in the first half of the year, but during the critical months, July to September, there was heavy rain in Abyssinia and round the Bahr el Jebel, and this condition persisted into the last quarter. The low stage preceding the flood was very satisfactory and water was plentiful. The flood started well in April, but was subject subsequently to several fluctuations; from November I the fall was rapid, but the river remained above its normal level.

In our "Notes" column of April 25 we made a brief reference to a report on the climate of Tripoli by Dr. Philip Eredia, based on direct observations between I892 and I9II. He has now supplemented that useful paper by one on the diurnal range of temperature, based on readings of a self-recording thermometer since September, 1905 (Rendiconti $R$. Accad. Lincei, July, 1912). The tables contain, inter alia, ten-day and monthly means for every even hour (2h., 4h., \&c.). These shov that the highest mean values occur about 2 h. p.m., and differ little from those at other hours near that time, except in the decades of the extreme months; the lowest readings generally occur near sunrise, as is usually the case. The mean daily extremes occur early in February ( $11^{\circ} 4^{\circ} \mathrm{C}$.) and about the middle of August $\left(26^{\circ} 5^{\circ}\right)$, giving a mean range of $15^{\circ} \mathrm{C}$., which differs little from that of the coastal towns of southern Italy. The peculiarities exhibited by the hourly means in the various months are well shown by thermo-isopleths.

We have received Nos. $7-9$ of the Finländische hydrographisch-biologische Untersuchungen in the gulfs of Bothnia and Finland and the northern part of the Baltic Sea during the years 1900-rgro. These very valuable observations and results, including sea- temperature at various depths, salinity, wind direction and force, and other data at lightships, lighthouses, and other fixed stations, as well as during expeditions to sea, have been discussed by Dr. Rolf Witting, director of the investigations, and translated into German by Mrs. Ellen Witting. The principal results are also shown graphically by a number of coloured plates. We note that the author is of opinion that more importance should be given to detailed observations at fixed stations in supplementing the observations made in the open sea than has hitherto been the case. The discussion covers too wide a range to allow of our entering into further details here, but we may mention that one of the chapters contains an interesting historical account of the development of our knowledge of the hydrography of the Baltic prior to the commencement of the international exploration of the ocean.

\section{THE BRITISH ASSOCIATION AT DUNDEE. SECTION I.}

PHYSIOLOGY.

Opening Address bY Leonard Hill, M.B., F.R.S., President of the Section.

LAST year the distinguished president of this section raised us to the contemplation of the workings of the soul. I ask you to accompany me in the consideration of nothing higher than a stuffy room. Everyone thinks that he suffers in an ill-ventilated room owing to some change in the chemical quality of the air, be it want of oxygen, or excess of carbon dioxide, the addition of some exhaled organic poison, or the destruction of some subtle property by passage of the air over steam-coils, or other heating or conducting apparatus. We hear of "devitalised" or "dead" air, and of "tinned" or "potted" air of the battleship. The good effects of open-air treatment, sea and mountain air, are no less generally ascribed to the chemical purity of the air. In reality the health-giving properties are those of temperature, light, movement, and relative moisture of the surrounding atmosphere, and leaving on one side those gross chemical impurities which arise in mines and in some manufacturing processes, and the question of bacterial infection, the alterations in chemical composition of the air in buildings where people crowd together and suffer from the effects of ill-ventilation have nothing to do with the causation of these effects.

Satisfied with the maintenance of a specious standard of chemical purity, the public has acquiesced in the elevation of sky-scrapers and the sinking of cavernous places of business. Many have thus become cave-dwellers, confined for most of their waking and sleeping hours in windless places, artificially lit, monotonously warmed. The sun is cut off by the shadow of tall buildings and by smoke-the sun, the energiser of the world, the giver of all things which bring joy to the heart of man, the fitting object of worship of our forefathers.

The ventilating and heating engineer hitherto has followed a great illusion in thinking that the main objects to be attained in our dwellings and places of husiness are chemical purity of the air and a uniform draughtless summer temperature.

Life is the reaction of the living substance to the ceaseless play of the environment. Biotic energy arises from the transformation of those other forms of energy-heat, light, sound, \&c.-which beat upon the transformer-the living substance (B. Moore). Thus, when all the avenues of sense are closed, the central nervous system is no longer aroused and con-

NO. 2240 , VOL. 90] 
sciousness lapses. The boy paralysed in almost all his avenues of sense fell asleep whenever his remaining eye was closed. The patient who lost one labyrinth by disease, and, to escape unendurable vertigo, had the other removed by operation, was quite unable to guide his movements or realise his position in the dark. Rising from bed one night, he collapsed on the floor and remained there helpless until succour arrived.

A sense organ is not stimulated unless there is a change of rate in the transference of energy; and this to be effectual must occur in most cases with considerable quickness. If a weak agent is to stimulate, its application must be abrupt (Sherrington). Thus the slow changes of barometric pressure on the bodysurface originate no skin sensations, though such changes of pressure if applied suddenly, are much above the threshold value for touch. A touch excited by constant mechanical pressure of slight intensity fades quickly below the threshold of sensation. Thus the almost unbearable discomfort which a child feels on putting on for the first time a "natural " wool vest fades away, and is no longer noticed with continual wear. Thomas a Beckett soon must have become oblivious to his hair-shirt, and even to its harbingers. It is not the wind which God tempers to the shorn lamb but the skin of the lamb to the wind. The inflow of sensations keeps us active and alive and all the organs working in their appointed functions. The cutaneous sensations are of the highest importance. The salt and sand of wind-driven sea air particularly act on the skin and through it brace the whole body. The changing play of wind, of light, cold, and warmth stimulate the activity and health of mind and body. Monotony of sedentary occupation and of an overwarm still atmosphere endured for long working hours destroys vigour and happiness and brings about the atrophy of disuse. We hear a great deal of the degeneration of the race brought about by city life, but observation shows us that a drayman, navvy, or policeman can live in London, or other big city, strong and vigorous, and no less so than in the country. The brain-worker, too, can keep himself perfectly fit if his hours of sedentary employment are not too long and he balances these by open-air exercise. The horses stabled, worked, and fed in London are as fine as any in the world; they do not live in windless rooms heated by radiators.

The hardy men of the north were evolved to stand the vagaries of climate-cold and warmth-a starved or full belly have been their changing lot. The full belly and the warm sun have expanded them in lazy comfort; the cold and the starvation have braced them to action. Modern civilisation has withdrawn many of us from the struggle with the rigours of nature : we seek for and mostly obtain the comfort of a full belly and expand all the time in the warm atmosphere afforded us by clothes, wind-protected dwellings, and artificial heat-particularly so in the winter, when the health of the business man deteriorates. Cold is not comfortable, neither is hunger; therefore we are lcd to ascribe many of our ills to exposure to cold, and seek to make ourselves strong by what is termed good living. I maintain that the bracing effect of cold is of supreme importance to health and happiness, that we become soft and flabby and less resistant to the attacks of infecting bacteria in the winter, not because of the cold, but because of our excessive precautions to preserve ourselves from cold; that the prime cause of "cold" or "chill" is not really exposure to cold, but to the overheated and confined air of rooms, factories, and meeting-places. Seven hundred and eleven survivors were saved from the Titanic after hours of exposure to cold. Many were insufficiently clad and others wet to the skin. Only one died after reaching the Carpathia, and he three hours after being picked up. Those who died perished from actual cooling of the body. Exposure to cold did not cause in the survivors the diseases commonly attributed to cold.

Conditions of city and factory life diminish the physical and nervous energy, and reduce many from the vigorous health and perfectness of bodily functions which a wild animal possesses to a more secure, but poorer and far less happy, form of existence. The illchosen diet, the monotony and sedentary nature of daily work, the windless uniformity of atmosphere, above all, the neglect of vigorous muscular exercise in the open air and exposure to the winds and light of heaven-all these, together with the difficulties in the way of living a normal sexual life, go to make the pale, undeveloped, neurotic, and joyless citizen. Nurture in unnatural surroundings, not nature's birthmark, moulds the criminal and the wastrel. The environment of childhood and youth is at fault rather than the stock; the children who are taken away and trained to be sailors, those sent to agricultural pursuits in the Colonies, those who become soldiers, mav develop a physique and bodilv health and vigour in striking contrast to their brothers who become clerks, shop assistants, and compositors.

Too much stress cannot be put on the importance of muscular exercise in regard to health, beauty, and happiness. Each muscle fills with blood as it relaxes, and expels this blood on past the venous valves during contraction. Each muscle, together with the venous valves, forms a pump to the circulatory system. It is the function of the heart to deliver the blood to the capillaries, and the function of the muscles-visceral, respiratory, and skeletal-to bring it back to the heart. The circulation is contrived for a restless mobile animal; every vessel is arranged so that muscular movement furthers the flow of blood.

The pressure of the blood in the veins and arteries under the influence of gravity varies with every change of posture. The respiratory pump, too, has a profound influence on the circulation. Active exercise, such as is taken in a game of football, entails endless changes of posture, varying compressive actions-one with another struggling in the rough and tumble of the game-forcible contractions and relaxations of the muscles, and a vastly increased pulmonary ventilation; at the same time the heart's action is accelerated and augmented and the arterial supply controlled by the vasomotor system. The influence of gravity, which tends to cause the fluids of the body to sink into the lower parts, is counteracted; the liver is rhvthmically squeezed like a sponge by the powerful respiratory movements, which not only pump the blood through the abdominal viscera but thoroughly massage these organs, and kneading these with the omentum clean the peritoneal cavity and prevent constipation. At the same time the surplus food metabolic products, such as sugar and fat, stored in the liver, are consumed in the production of energy, and the organs swept with a rapid stream of blood containing other products of muscular metabolism which are necessary to the interrelation of chemical action. The output of energy is increased very greatly; a resting man may expend two thousand calories per diem; one bicycling hard for most of the day expended eight thousand calories, of which only four thousand was covered by the food eaten.

Such figures show how fat is taken off from the body by exercise, for the other four thousand calories comes from the consumption of surplus food products stored in the tissues. While resting a man breathes some 7 litres of air, and uses 300 c.c. of oxygen per minute, against 140 litres and 3000 c.c. while doing very hard labour. The call of the muscles for oxygen No. 2240, vol. 90] 
through such waste products as lactic acid impels the formation of red corpuscles and hæmoglobin. The products of muscular metabolism in other ways not yet fully defined modify the metabolism of the whole body.

Exposure to cold, cold baths, and cold winds has a like effect, accelerating the heart and increasing the heat production, the activity of the muscles, the output of energy, the pulmonary ventilation, and intake of oxygen and food. In contrast with the soft potbellied, over-fed city man the hard, wiry fisherman trained to endurance has no superfluity of fat or tissue fluid. His blood volume has a high relative value in proportion to the mass of his body. His superficial veins are confined between a taut skin and muscles, hard as in a racehorse trained to perfection. Thus the adequacy of the cutaneous circulation and loss of heat by radiation rather than by sweating is assured. His fat is of a higher melting point, hardened by exposure to cold. In him less blood is derived to other parts, such as adipose tissue, skin, and viscera $\mathrm{He}$ uses up the oxygen in the arterial blood more completely and with greater efficiency; for the output of each unit of energy his heart has to circulate much less blood (Kreogh); his blood is sent in full volume by the well. balanced activity of his vasomotor system to the moving parts. Owing to the perfect coordination of his muscles, trained to the work, and the efficient action of his skin and cutaneous circulation-the radiator of the body-he performs the work with far greater economy and less fatigue. The untrained man may obtain 12 per cent. of his energy output as work, against 30 per cent, or perhaps even 50 per cent., obtained by the trained athlete. Hence the failure and risk suffered by the city man who rushes straight from his office to climb the Alps. On the other hand, the energetic man of business or brain worker is kept by his work in a state of nervous tension. He considers alternative lines of action, but scarcely moves. He may be intensely excited, but the natural muscular response does not follow. His heart is accelerated and his blood pressure raised, but neither muscular movements and accompanying changes of posture, nor the respiratory pump materially aid the circulation. The activity of his brain demands a rapid flow of blood, and his heart has to do the circulatory work, as he sits still or stands at his desk, against the influence of gravity. Hence a high blood pressure is maintained for long periods at a time by vasoconstriction of the arteries in the lower parts of the body and increased action of the heart; hence, perhaps, arise those degenerative changes in the circulatory system which affect some men tireless in their mental activity. We know that the bench-worker, who stands on one leg for long hours a day, may suffer from degeneration and varicosity of the veins in that leg. Long-continued high arterial pressure, with systolic and diastolic pressures approximately the same, entails a stretched arterial wall, and this must impede the circulation in the vaso-vasorum, the flow of tissue lymph in, and nutrition of, the wall. Since his sedentary occupation reduces the metabolism and heat production of his body very greatly, the business man requires a warmer atmosphere to work in. If the atmosphere is too warm it reduces his metabolism and pulmonary ventilation still further; thus he works in a vicious circle. Exhausting work causes the consumption of certain active principles, for example, adrenin, and the reparation of those must be from the food. To acquire certain of the rarer principles expended in the manifestation of nervous energy more food may have to be eaten by the sedentary worker than can be digested and metabolised. His digestive organs lack the kneading and massage the rapid circulation and oxidation of fondstuffs which is given by muscular exercise. Hence arise the digestive and metabolic ailments so common to brain workers.

Mr. Robert Milne informs me that of the thousands of children who have passed through Barnardo's Homes-there are 9000 in the homes at any one time -not one after entering the institution and passing under its regimen and the care of his father, Dr. Milne, has developed appendicitis. Daily exercise and play, adequate rest, a regular, simple diet have ensured their immunity from this infection. It pays to keep a horse healthy and efficient; it no less pays to keep men healthy. I recently investigated the case of clerks employed in a great place of business, whose working hours are from 9 to 6 on three days, and 7 to 9 on the other three days of each week, and working such overtime, they make $1 l$. to $2 l$. a week; these clerks worked in a confined space-forty or fifty of them in 8200 cubic feet, lit with thirty electric lamps, cramped for room, and overheated in warm summer days. It is not with the chemical purity of the air of such an office that fault is to be found, for fans and large openings ensured this sufficiently. These clerks suffered from their long hours of monotonous and sedentary occupation, and from the artificial light, and the windless, overwarm and moist atmosphere. Many a girl cashier has worked from 8 to 8.30 , and on Saturdays from 8 to ro, and then has had to balance her books and leave perhaps after midnight on Sunday morning. Her office is away in the background-confined, windless, artificially lit. The Shops Act has given a little relief from these hours. What, I ask, is the use of the State spending a million a year on sanatoria and tuberculin dispensaries, when those very conditions of work continue which lesson the immunity and increase the infection of the workers?

The jute industry in this town of Dundee is carried out almost wholly by female and bov labour. "The average wages for women are below $12 s$. in eight processes, and above I2s., but under $18 s$., for the remaining five processes." The infant mortality has been more than i70 per 1000. The Social Union of Dundee reported in 1905 that of 885 children born to 240 working mothers no fewer than 520 , or 59 per cent., died-and almost all of them were under five years of age. The life of these mothers was divided between the jute factory and the one-roomed tenement. Looking such conditions squarely in the face, I sav it would be more humane for the State to legalise the exposure of every other new-born infant on the hillside rather than allow children to be slowly done to death. The conditions, as given in the report, contravene those rights of motherhood which the meanest wild animal can claim.

Isolation hospitals, sputum-pots and anti-spitting regulations will not stamp out tuberculosis. Such means are like shutting the door of the stable when the horse has escaped. Flügge has shown that tubercle bacilli are spread bv the droplets of saliva which are carried out as an invisible spray when we speak, sing. cough. sneeze. Sputum-pots cannot control this. The saliva of cases of phthisis may teem with the bacilli. The tuberculin reaction tests carried out by Hamburger and Monti in Vienna show that 94 per cent. of all children aged eleven to fourteen have been infected with tubercle. In most the infection is a mere temporary indisposition. I believe that the conditions of exhausting work, and amusement in confined and overheated atmospheres, together with ill-regulated feeding, determine largely whether the infection, which almost none can escape. become serious or not. Karl Pearson suggests that the death statistics afford no proof of the utility of sanatoria or tuberculin dispensaries, for during the very vears in which such treatment has been in vogue, the fall in NO. 2240 , VOL. 90] 
the mortality from tuberculosis has become less relatively to the fall in general mortality. He opines that the race is gradually becoming immune to tubercle, and hence the declination in the mortality curve is becoming flattened out-that nature is paramount as the determinant of tuberculosis, not nurture. From a statistical inquiry into the incidence of tuberculosis in husband and wife and parent and child, Pearson concludes that exposure to infection as in married couples is of little importance, while inborn immunity or diathesis is - a chief determinant. Admitting the value of his critical inquiries and the importance of diathesis, I would point out that in the last few years the rush and excitement of modern city life has increased, together with the confinement of workers to sedentary occupations in artificially lit, warm, windless atmospheres. The same conditions pertain to places of amusement, eating-houses, tube railways, \&c.

Central heating, gas-radiators, and other contrivances are now displacing the old open. fire and chimney. This change greatly improves the economical consumption of coal and the light and cleanliness of the atmosphere. But in so far as it promotes monotonous, windless, warm atmospheres, it is wholly against the health and vigour of the nation. The open fire and wide chimney ensure ventilation, the indrawing of cold outside air, streaky air-restless currents at different temperatures, which strike the sensory nerves in the skin and prevent monotony and weariness of spirit. By the old open fires we were heated with radiant heat. The air in the rooms was drawn in cool and varied in temperature. The radiator and hot-air svstem give us a deadly uniformly heated air - the very conditions we find most unsupportable on a close summer's day.

In Labrador and Newfoundland, Dr. Wakefield tells me, the mortality of the fisherfolk from tube:-culosis is very heavy. It is generally acknowledged to be four per rooo of the population per annum, against $\mathbf{I}^{\circ} \mathbf{5}_{2}$ for England and Wales. Some of the Labrador doctors talk of seven and even eight per rooo in certain districts. The general death-rate is a low one. The fishermen fish off shore, work for many hours a day in the fishing season, and live with their families on shore in one-roomed shanties. These shanties are built of wood, the crannies are "stogged" with moss, and the windows nailed up, so that ventilation is very imperfect. They are heated by stoves and kept at a very high temperature, e.g., $80^{\circ} \mathrm{F}$. Outside in the winter the temperature may be 30 degrees below freezing. The women stay inside the shanties almost all their time, and the tuberculosis rate is somewhat higher in them. The main food is white bread, tea stewed in the pot till black, fish occasionally, a little margarine and molasses. The fish is boiled and the water thrown away. Game has become scarce in recent years; old, dark-coloured flour-spoken of with disfavour-has been replaced by white flour. In consequence of this diet beri-beri has become rife to a most serious extent, and the hospitals are full of cases. Martin Flack and I have found by our feeding experiments that rats, mice, and pigeons cannot be maintained on white bread and water, but can live on wholemeal, or on white bread in which we incorporate an extract of the sharps and bran in sufficient amount. Recent work has shown the vital importance of certain active principles present in the outer layers of wheat, rice, \&c., and in milk, meat, \&c., which are destroyed by heating to $120^{\circ} \mathrm{C}$. A diet of white bread or polished rice and tinned food sterilised by heat is the cause of beri-beri. The metabolism is endangered by the artificial methods of treating foods now in vogue. As to the prevalency of tuberculosis in Labrador, we have to consider the intermarriage, the bad diet, the over-rigorous work NO. 2240 , VOL. 90] of the fishermen, the overheating of, and infection in, the shanties. Dr. Wakefield has slept with four other travellers in a shanty with father, mother, and ten children. In some there is scarce room on the floor to lie down. The shanties are heated with a stove on which pots boil all the time; water runs down the windows. The patients are ignorant, and spit everywhere, on bed, floor, and walls. In the schools the heat and smell are most marked to one coming in from the outside air. In one school 50 cubic feet per child is the allowance of space. The children are eating all day long, and are kept in close hot confinement. They suffer very badly from decay of the teeth. Whole families are swept off with tuberculosis, and the child who leaves home early may escape, while the rest of a family dies.

Here, then, we have people living in the wildest and least populated of lands with the purest atmosphere suffering from all those ill-results which are found in the worst city slums-tuberculosis, beriberi, and decayed teeth.

The bad diet probably impels the people to conserve their body heat and live in the over-warm, confined atmosphere, just as our pigeons fed on white bread sit, with their feathers out, huddled together to keep each other warm. The metabolism, circulation, respiration, and expansion of the lung are all reduced. The warm, moist atmosphere lessens the evaporation from the respiratory tract, and therefore the transudation of tissue lymph and activity of the ciliated epithelium. The unexpanded parts of the lung are not swept with blood. Everything favours a lodgment of the bacilli, and lessens the defences on which immunity depends. In the mouth, too, the immune properties of the saliva are neutralised by the continual presence of food, and the temperature of the mouth is kept at a high level, which favours bacterial growth. Lieutenant Siem informs me that recently in Northern Norway there has been the same notable increase in tuberculosis. The old cottage fireplaces with wide chimneys have been replaced with American stoves. In olden days most of the heat went up the chimney, and the people were warmed by radiant heat. Now the room is heated to a uniform moist heat. The Norwegians nail up the windows and never open them during the winter. At Lofoten, the great fishing centre, motor-boats have replaced the old open sailing and row boats. The cabin in the motor-boat is very confined, covered in with watertight deck, heated by the engine, crowded with six or eight workers. When in harbour the fishermen used to occupy ill-fitted shanties, through which the wind blew freely; now, to save rent, they sleep in the motor-boat cabins.

Here, again, we have massive infection, and the reduction of the defensive mechanisms by the influence of the warm, moist atmosphere.

The Norwegian fishermen feed on brown bread, boiled fish, salt mutton, margarine, and drink, when in money, beer and schnapps; there is no gross deficiency in diet, as in Labrador, and beri-beri does not attack them. They return home to their villages and longshore fishing when the season is over. The one new condition which is common to the two districts is confinement in stove-heated, windless atmospheres. In old days the men were crowded together, but in open boats or in draughty shanties, and had nothing but little cooking-stoves.

The conditions of great cities tend to confine the worker in the office all way, and to the heated atmosphere of club, cinema show, or music hall in the evening. The height of houses prevents the town dweller from being blown upon by the wind, and, missing the exhilarating stimulus of the cool, moving air, he repels the dull uniformity of existence by tobacco 
and by alcohol, or by indulgence in food, e.g., sweets, which are everywhere to his hand, and by the nervous excitement of business and amusement. He works, he eats, and is amused in warm, windless atmospheres, and suffers from a feeble circulation, a shallow respiration, a disordered digestion, and a slow rate of metabolism.

Many of the employments of modern days are detestable in their long hours of confinement and monotony. Men go up and down in a lift all day, and girls in the bloom of youth are set down in tobacco stalls in underground stations, and their health and beauty there fade while even the blow-flies are free to bask in the sun. In factories the operatives feed machines, or reproduce the same small piece of an article day after day. There is no art, or change; no pleasure in contrivance and accomplishment. The miner, the fisherman, even the sewer-man, face difficulties, changing risks, and are developed as men of character and strength. Contrast the sailor with the steward on a steamer, the drayman outside with the clerk inside who checks the goods delivered at some city office the butcher and the tailor, the seamstress and the market woman, and one sees the enormous difference. which a confined occupation makes. Monotonous sedentary employment makes for unhappiness because the inherited functional needs of the human body are neglected, and education-when the outside field of interest is narrowed-intensifies the sensitivity to the bodily conditions. The sensations arising within the body-proprioceptive sensationscome to have too large a share in consciousness in comparison with exteroceptive. In place of considering the lilies how they grow, or musing on the beauty and motions of the heavenly bodies, the sedentary worker in the smoke-befouled atmosphere, with the limited activity and horizon of an office and a disturbed digestion, tends to become confined to the inward consideration of his own viscera and their motions.

Many of the educated daughters of the well-to-do are no less confined at home; they are the flotsam and jetsam cast up from the tide in which all others struggle for existence-their lives are no less monotonous than the sweated sempstress or clerk. They become filled with "vapours" and some seek excitement not at the cannon's mouth but in breaking windows, playing with fire, and hunger strikes. The dull monotony of idle social functions, shopping and amusement no less than that of sedentary work and an asexual life, impels to a simulated struggle-a theatrical performance, the parts of which are studied from the historical romances of revolution. Each man, woman, and child in the world must find the wherewithal for living, food, raiment, warmth, and housing, or must die or get some other to find it for him. It seems to me as if the world is conducted as if ten men were on an island-a microcosm-and five sought for the necessaries of life, hunted for food, built shelters and fires, made clothes of skins, while the other five strung necklaces of shells, made loincloths of butterfly wings, gambled with knuckle-bones, drew comic pictures in the sand, or carved out of clay frightening demons, and so beguiled from the first five the larger share of their wealth. In this land of factories, while the many are confined to mean streets and wretched houses, possessing no sufficiency of baths and clean clothing, and are ill-fed, they work all day long, not to fashion for themselves better houses and clothing, but to make those unnecessaries such as "the fluff" of women's apparel, and a thousand trifles which relieve the monotony of the idle and bemuse their own minds.

The discovery of radium and its disintegration as a source of energy has enabled the physicist to extend Lord Kelvin's estimate of the world's age from some thirty to a thousand million years. Arthur Keith does not hesitate to give a million of these years to man's evolution. Karl Pearson speaks of hundreds of thousands of years. The form of the human skull, the brain capacity of man, his skill as evidenced by stone implements and cave drawings of animals in action, was the same tens of thousands of years ago as now For ages primitive man lived as a wild animal in tropical climes, discovered how to make fire, clothe himself in skins, build shelters, and so enable himself to wander over the temperate and arctic zones. Finally, in the last few score of years, he has made houses draughtless with glass windows, fitted them with stoves and radiators, and every kind of device to protect himself from cold, while he occupies himself in the sedentary pursuits and amusements of a city life. How much better, to those who know the boundless horizon of life, to be a frontiersman and enjoy the struggle, with body hardened, perfectly fit, attuned to nature, than to be a cashier condemned to the occupation of a sunless, windless pay-box. The city child, however, nurtured and educated in confinement, knows not the largeness and wonders of Nature, is used to the streets with their ceaseless movement and romantic play of artificial light after dark, and does not need the commiseration of the country mouse any more than the beetle who lives in the dark and animated burrows of his heap. But while outdoor work disciplines the body of the countryman into health, the town man needs the conscious attention and acquired educated control of his life to give him any full measure of health and happiness.

Experimental evidence is strongly in favour of my argument that the chemical purity of the air is of no importance. Analyses show that the oxygen in the worst-ventilated school-room, chapel, or theatre is never lessened by more than I per cent. of an atmosphere; the ventilation through chink and cranny, chimney, door, and window, and the porous brick wall, suffices to prevent a greater diminution. So long as there is present a partial pressure of oxygen sufficient to change the hæmoglobin of the venous blood into oxyhæmoglobin there can arise no lack of oxygen.

At sea-level the pressure of oxygen in the pulmonary alveolar air is about $100 \mathrm{~mm}$. Hg. Exposed to only half this pressure the hæmoglobin is more than 80 per cent. saturated with oxygen.

In noted health-resorts of the Swiss mountains the barometer stands at such a height that the concentration of oxygen is far less than in the more ventilated room. On the high plateau of the Andes there are great cities: Potosi with a hundred thousand inhabitants is at $4,16_{5}$ metres, and the partial pressure of oxygen there is about 13 per cent. of an atmosphere in place of $7 \mathbf{I}$ per cent. at sea-level; railways and mines have been worked up to altitudes of 14,000 to 15,000 feet. At Potosi girls dance half the night, and toreadors display their skill in the ring. On the slopes of the Himalayas shepherds take their flocks to altitudes of 18,000 feet. No disturbance is felt by the inhabitants or those who reach these great altitudes slowly and by easy stages. The only disability to a normal man is diminished power for severe exertion, but a greater risk arises from want of oxygen to cases of heart disease, pneumonia, and in chloroform anæsthesia at these high altitudes. The newcomer who is carried by the railway in a few hours to the top of Pike's Peak or the Andes may suffer severely from mountain sickness, especially on exertion, and the cause of this is want of oxygen. Acclimatisation is brought about in a few days' time. The pulmonary ventilation increases, the bronchial tubes dilate, the circulation becomes more rapid. The increased pulmonary ventilation lowers the partial pressure of carbon dioxide in the blood and pulmonary air, and this conNO. 2240 , VOL. 907 
tributes to the maintenance of an adequate partial pressure of oxygen. Haldane and Douglas say that the percentage of red corpuscles and total quantity of the hæmoglobin increases, and maintain that the oxygen is actively secreted by the lung into the blood, but the $\mathrm{CO}$ method by which their determinations have been made has not met with unqualified acceptance. If waste products, which arise from oxygen want, alter the combining power of hæmoglobin, this alteration may not persist in shed blood; for these products may disappear when the blood is exposed to air. Owing to the combining power of hæmoglobin the respiratory exchange and metabolism of an animal within wide limits are independent of the partial pressure of oxygen. On the other hand, the process of combustion is dependent not on the pressure, but on the percentage of oxygen. Thus the aeroplanist may become seized with altitude sickness from oxygen want, while his gas engine continues to carry him to loftier heights.

The partial pressure of oxygen in a mine at a depth of 3000 feet is considerably higher than at sea-level, and if the percentage is reduced to 17 , while the firing of fire-damp and coal-dust is impossible, there need be in the alveolar air of the lungs no lower pressure of oxygen than at sea-level. Thus the simplest method of preventing explosions in coal mines is that proposed by I Harger, viz., to ventilate them with air containing 17 per cent. of oxygen. ${ }^{1}$ There is little doubt that all the great mine-explosions have been caused by the enforcement of a high degree of chemical purity of the air. In the old days when ventilation was bad there were no great dust explosions. Mr. W. H. Chambers, general manager of the Cadeby mine, where the recent disastrous explosion occurred, with the authority of his great and long practical experience of fiery mines, told me that the spontaneous combustion of coal and the danger of explosion can be wholly met by adequate diminution in ventilation. The fires can be choked out while the miners can still breathe and work. The Coal Mines Regulation Act enforces that a place shall not be in a fit state for working or passing therein, if the air contains either less than ig per cent. of oxygen, or more than $I \frac{1}{3}$ per cent. of carbon dioxide. A mine liable to spontaneous combustion of coal may be exempted from this regulation by order of the Secretary of State.

The regulations impel the provision of such a ventilation current that the percentage of oxygen is sufficient for the spread of dust explosions along the intake airways, with the disastrous results so frequently recorded. If the mine were ventilated with air containing I 7 per cent. of oxygen in sufficient volume to keep the miners cool and fresh, not only would explosions be prevented, but the mines could be safely worked and illuminated with electricity, and miners' nystagmus prevented, for this is due to the dim light of the safety lamp. The problem possibly may be solved by purifying and cooling the return air, and mixing and circulating this with a sufficiency of fresh air.

Owing to the fact that the percentage of $\mathrm{CO}_{2}$ is the usual test of ventilation and that only a very few parts per 10,000 in excess of fresh air are permitted by the English Factory Acts, it is generally supposed that $\mathrm{CO}_{2}$ is a poison, and that any considerable excess has a deleterious effect on the human body. No supposition could be further from the truth.

The percentage of $\mathrm{CO}_{2}$ in the worst ventilated room does not rise above $0^{\circ} 5$ per cent., or at the outside I per cent. It is impossible that any excess of $\mathrm{CO}_{2}$ should enter into our bodies when we breathe such air, for whatever the percentage of $\mathrm{CO}_{2}$ in the atmosphere may be, that in the pulmonary air is kept 1 Trans. Inst. of Miniag Engineers, rgr2.

NO. 2240, VOL. 90] constant at about 5 to 6 per cent. of an atmosphereby the action of the respiratory centre. It is the concentration of $\mathrm{CO}_{2}$ which rules the respiratory centre, and to such purpose as to keep the concentration both in the lungs and in the blood uniform (Haldane); the only result from breathing air containing $0^{\circ} 5$ to I per cent. of $\mathrm{CO}_{2}$ is an inappreciable increase in the ventilation of the lungs. The very same thing happens when we take gentle exercise and produce more $\mathrm{CO}_{2}$ in our bodies.

At each breath we rebreathe into our lungs the air in the nose and large air-tubes (the dead-space air), and about one-third of the air which is breathed in by a man at rest in dead-space air. Thus, no man breathes in pure outside air into his lungs. When a child goes to sleep with its head partly buried under the bedclothes, and in a cradle confined by curtains, he rebreathes the expired air to a still greater extent, and so with all animals that snuggle together for warmth's sake. Not only the new-born babe sleeping against its mother's breast, but pigs in a sty, young rabbits, rats, and mice clustered together in their nests, young chicks under the brooding hen, all alike breathe a far higher percentage than that allowed by the Factory Acts.

To rebreathe one's own breath is a natural and inevitable performance, and to breathe some of the air exhaled by another is the common lot of men who, like animals, have to crowd together and husband their heat in fighting the inclemency of the weather.

In the Albion Brewery we analysed on three different days the air of the room where the $\mathrm{CO}_{2}$ generated in the vats is compressed and bottled as liquid carbonic acid. We found from o: 14 to $0^{\circ} 93$ per cent. of $\mathrm{CO}_{2}$ in the atmosphere of that room. The men who were filling the cylinders and turning the taps on and off to allow escape of air must often breathe more than this. The men engaged in this occupation worked twelve-hour shifts, having their meals in the room. Some had followed the same employment for eighteen years, and without detriment to their health. It is only when the higher concentrations of $\mathrm{CO}_{2}$ are breathed, such as 3 to 4 per cent. of an atmosphere, that the respiration is increased, so that it is noticeable to the resting individual; but percentages over I per cent. diminish the power to do muscular work, for the excess of $\mathrm{CO}_{2}$ produced by the work adds its effect to that of the excess in the air, and the difficulty of coordinating the breathing to the work in hand is increased.

Haldane and Priestley found that with a pressure of 2 per cent. of an atmosphere of $\mathrm{CO}_{2}$ in the inspired air the pulmonary ventilation of a man at rest was increased 50 per cent., with 3 per cent. about Ioo per cent., with 4 per cent. about 200 per cent., with 5 per cent. about 300 per cent., and with 6 per cent. about 500 per cent. With the last, panting is severe, while with 3 per cent. it is unnoticed until muscular work is done, when the panting is increased roo per cent. more than usual. With more than 6 per cent. the distress is very great, and headache, flushing, and sweating occur.

Divers who work in diving dress and men who work in compressed-air caissons constantly do heavy and continuous labour in concentrations of $\mathrm{CO}_{2}$ higher than I per cent. of an atmosphere, and so long as the $\mathrm{CO}_{2}$ is kept below 2 to 3 per cent. they are capable of carrying out efficient work. In the case of workers in compressed air it is important to bear in mind that the effect of the $\mathrm{CO}_{2}$ on the breathing depends on the partial pressure and not on the percentage of this gas in the air breathed.

By a series of observations made on rats confined 
in cages fitted with small, ill-ventilated sleepingchambers, we have found that the temperature and humidity of the air-not the percentage of carbon dioxide or oxygen-determines whether the animals stay inside the sleeping-room or come outside. When the air is cold, they like to stay inside, even when the carbon dioxide rises to 4 to 5 per cent. of an atmosphere. When the sleeping-chamber is made too hot and moist they come outside.

The sanitarian says it is necessary to keep the $\mathrm{CO}_{2}$ below o*or per cent., so that the organic poisons may not collect to a harmful extent. The evil smell of crowded rooms is accepted as unequivocal evidence of the existence of such. He pays much attention to this and little or none to the heat and moisture of the air. The smell arises from the secretions of the skin, soiled clothes, \&c. The smell is only serised by and excites disgust in one who comes to it from the outside air. He who is inside and helps to make the "fugg" is both wholly unaware of, and unaffected by it. Flügge points out, with justice, that while we naturally avoid any smell that excites disgust and puts us off our appetite, yet the offensive quality of the smell does not prove its poisonous nature. For the smell of the trade or food of one man may be horrible and loathsome to another not used to such.

The sight of a slaughterer and the smell of dead meat may be loathly to the sensitive poet, but the slaughterer is none the less healthy. The clang and jar of an engineer's workshop may be unendurable to a highly-strung artist or author, but the artificers miss the stoppage of the noisy clatter. The stench of glue-works, fried-fish shops, soap and bone-manure works, middens, sewers, become as nothing to those engaged in such, and the lives of the workers are in no wise shortened by the stench they endure. The nose ceases to respond to the uniformity of the impulse, and the stench clearly does not betoken in any of these cases the existence of a chemical organic poison. On descending into a sewer, after the first ten minutes the nose ceases to smell the stench; the air therein is usually found to be far freer from bacteria than the air in a schoolroom or tenement.

If we turn to foodstuffs we recognise that the smell of alcohol and of Stilton or Camembert cheese is horrible to a child, while the smell of putrid fish-the meal of the Siberian native-excites no less disgust in an epicure, who welcomes the cheese. Among the hardiest and healthiest of men are the North Sea fishermen, who sleep in the cabins of trawlers reeking with fish and oil, and for the sake of warmth shut themselves up until the lamp may go out from want of oxygen. The stench of such surroundings may effectually put the sensitive, untrained brain worker off his appetite, but the robust health of the fisherman proves that this effect is nervous in origin, and not due to a chemical organic poison in the air.

Ventilation cannot get rid of the source of a smell, while it may easily distribute the evil smell through a house. As Pettenkofer says, if there is a dungheap in a room, it must be removed. It is no good trying to blow away the smell.

Flügge and his school bring convincing evidence to show that a stuffy atmosphere is stuffy owing to heat stagnation, and that the smell has nothing to do with the origin of the discomfort felt by those who endure it. The inhabitants of reeking hovels in the country do not suffer from chronic ill-health, unless want of nourishment, open-air exercise, or sleep come into play. Town workers who take no exercise in the fresh air are pale, anæmic, listless. Sheltered by houses they are far less exposed to winds, and live day and night in a warm. confined atmosphere.

The widespread belief in the presence of organic poisons in the expired air is mainly based on the stateNO. 2240, vOL. 907 ments of Brown Sequard and D'Arsenval, statements wholly unsubstantiated by the most trustworthy workers in Europe and America. These statements have done very great mischief to the cause of hygiene, for they led ventilating engineers and the public to seek after chemical purity, and neglect the attainment of adequate coolness and movement of the air. It was stated that the condensation water obtained from expired air is poisonous when injected into animals. The evidence on which this statement is based is not only not worthy of credence but is absurd, e.g. condensation water has been injected into a mouse. in a quantity equivalent to injecting 5 kilogrammes into a man weighing 60 kilogrammes. No proper controls were carried out. It is recognised now that any distilled water contaminated by bacterial products may have a toxic effect. Flack and I have for fourteen weeks kept guinea-pigs and rats confined together in a box and poorly ventilated, so that they breathed air containing $\mathrm{O}_{5}^{\circ}$ to $\mathrm{r}^{\circ} \mathrm{o}$ per cent. of $\mathrm{CO}_{2}$. The guinea-pigs proved wholly free from anaphylactic shock on injecting rats' serum. Therefore they were not sensitised by breathing the exhaled breath of the rats for many weeks, and we are certain that no foreign protein substance is absorbed in this way. It has been proved by others, and by us that animals so confined do well so long as they are well fed and their cages kept clean, light, cool, and dry. It is wholly untrue that they are poisoned by breathing each other's breath. The only danger arises from droplet contagion in cases of infective disease.

To study the relative effect of the temperature and chemical puricy of the atmosphere, I constructed a small experimental chamber of wood fitted with large glass observation windows and rendered airtight.

On one side of the chamber were fixed two small electric heaters, and a tin containing water was placed on these in order to saturate the air with water vapour. On another side of the chamber was placed a large radiator through which cold water could be circulated when required, so as to cool the chamber, In the roof were fixed three electric fans, one big and two small, by means of which the air of the chamber could be stirred. The chamber held approximately $3 \mathrm{~cm}$. of air. In one class of experiments we shut within the chamber seven or eight students for about half an hour, and observed the effect of the confined atmosphere upon them. We kept them until the $\mathrm{CO}_{2}$ reached 3 to $A$ per cent., and the oxygen had fallen to I7 to 16 per cent. The wet-bulb temperature rose meanwhile to about $80^{\circ}$ to $85^{\circ} \mathbf{F}$., and the dry-bulb a degree or two higher. The students went in chatting and laughing, but by and by, as the temperature rose, ther ceased to talk and their faces became flushed and moist. To relieve the monotony of the experiment we have watched them trying to light a cigarette, and, puzzled by their matches going out. borrowing others, anly in vain. They had not sensed the diminution of oxygen, which fell below i7 per cent. Their breathing was deepened by the high percentage of $\mathrm{CO}_{2}$, but no headache occurred in any of them from the short exposure. Their discomfort was relieved to an astonishing extent bv putting on the electric fans placed in the roof. Whilst the air was kept stirred the students were not affected by the oppressive atmosphere. They begged for the fans to be put on when the were cut off. The same old stale air containing 3 to 4 per cent. $\mathrm{CO}_{2}$ and $\mathrm{I} 6$ to $\mathrm{I} 7$ per cent. $\mathrm{O}_{2}$ was whirled, but the movement of the air gave relief, bocause the air was $80^{\circ}$ to $85^{\circ} \mathrm{F}$. (wet bulb), while the air enmeshed in their clothes in contact with their skin was $08^{\circ}$ to $99^{\circ} \mathrm{F}$. (wet bulb). If we outside breathed through a tube the air in the chamber we felt none of the discomfort which was being experienced by those shut up inside. Similarly, if one of 
those in the chamber breathed through a tube the pure air outside he was not relieved.

R. A. Rowlands and H. B. Walker carried out a large number of observations in the chamber, each acting as subject in turn.

They recorded the effect on the respiratory ventilation and on the pulse rate, both when resting and when working. The work consisted in pulling a 2o-kilo. weight about I metre high by means of a pulley and rope

In some of the experiments the exhaled carbonic acid was absorbed, and in others carbonic acid was put into the chamber. The subjects inside could not tell when the gas was introduced, not even if the percentage were suddenly raised by 2 . The introduction of this amount of the gas made no sensible difference to them, but increased their pulmonary ventilation.

In every one of the experiments they suffered from the heat, and the putting on of the fans gave great relief, and in particular diminished the pulse rate during and after the working periods. The relief became much greater when cold water was circulated through the radiator and the temperature of the chamber lowered $10^{\circ} \mathrm{F}$.

The subjects wore only a vest, pants, and shoes in most of these experiments. When they wore their ordinary clothing the effect on the frequency of the pulse was more marked and the discomfort from heat and moisture much greater.

I have made observations on men dressed in the Fleuss rescue apparatus for use in mines, and exposed in a chamber to $120^{\circ} \mathrm{F}$. dry bulb and $95^{\circ} \mathrm{F}$. wet bulb. The skin temperature rises to the rectal temperature and the pulse is greatly accelerated-e.g. to 150-and there arises danger of heat stroke. The conditions are greatly relieved by interposing on the inspiratory tube of the apparatus a cooler filled with carbonic acid snow. The cool inspired air lowers the frequency of the heart and makes it possible for the men to do some work at $95^{\circ} \mathrm{F}$. wet bulb, and to endure this temperature for two hours.

The observations made by Pembrey and Collis on the weaving-mill operatives at Darwen show that the skin of the face may be $4^{\circ}$ to $13^{\circ} \mathrm{F}$. higher in the mill when the wet bulb is $7 \mathrm{I}^{\circ} \mathrm{F}$. than at home when the wet-bulb temperature is about $55^{\circ} \mathrm{F}$. The tendency of the warm, humid atmosphere of the mill is to establish a more uniform temperature of the body as a whole (surface and deep temperatures) and to throw a tax upon the power of accommodation as indicated by the rapid pulse and low blood-pressure.

The mill workers are wet with the steam blown into the sheds, their clothes and bodies are moist, and the long hours of exposure to such uncomfortable conditions are most deleterious to physical vigour and happiness. The operatives asked that they might be allowed to work without steam-injectors and with diminished ventilation, so that the mill rooms became saturated with moisture evaporated from the bodies of the operatives. The old regulations, while forbidding more than 6 parts in $10,000 \mathrm{CO}_{2}$, put no limit to the wet-bulb temperature, and this often became excessive on hot summer days. The operatives were quite right. Less ventilation and a lower wet bulb is far better than ample ventilation and $a$ high wet bulb. The permissible limit of $\mathrm{CO}_{2}$ has now been raised to II parts in 10,000 , and the wet-bulb temperature is to be controlled within reasonable limits.

The efficiency of workers in mills, mines, tunnels, stoke-holes, \&c., is vastly increased by the provision of a sufficient draught of cool and relatively dry air, so as to prevent overtaxing of the heat-regulating mechanism. Mr. F. Green informs me that by means of forced draught the stokehole of an Orient steamer is rendered the coolest place when the ship is in the tropics.

The electric fan has vastly improved the conditions of the worker in the tropics. I would suggest that each clerk should have a fan just as much as a lamp on his desk. It will pay the employer to supply fans.

In the modern battleship men are confined very largely to places artificially lit and ventilated by air driven in by fans through ventilating-shafts. The heat and moisture derived from the bodies of the men, from the engines, from cooking-ranges, \&c., lead to a high degree of relative moisture, and thus all parts of the ironwork inside are coated with granulated cork to hold the condensed moisture and prevent dripping.

The air smells with the manifold smells of oil, cooking, human bodies, \&c., and the fresh air driven in by fans through the metal conduits takes up the smell of these, and is spoken of by the officers with disparagement as "tinned" or "potted" air. This air is heated when required by being made to pass over radiators. Many of the officers' cabins and offices for clerks, typewriters, \&c., in the centre of a battleship, have no portholes, and are only lit and ventilated by artificial means. The steel nature of the structure prevents the diffusion of air which takes place so freely through the brick walls of a house. The men in their sleeping quarters are very closely confined, and as the openings of the air-conduits are placed in the roof between the hammocks, the men next to such openings receive a cold draught and are likely to shut the openings. To sleep in a warm moist "fugg" would not much matter if the men were actively engaged for many hours of the day on deck and there exposed to the open air and the rigours of sea and weather. In the modern warship most of the crew work for many hours under deck, and some of the men may scarcely come on deck for weeks or even months. Considering the conditions which pertain, it seems to be of the utmost importance that all the men in a battleship should be inspected at short intervals by the medical officers so that cases of tuberculosis may be weeded out in their incipiency. The men of every rating should do deck drill for some part of every day. In the Norwegian navy every man, cooks and all, must do gymnastic drill on deck once a day. In the case of our navy, with voluntary service, the men should welcome this in their own interest.

In a destroyer visited by me twelve men occupied quarters containing about $\mathbf{1 7 0 0}$ cubic feet of air. There was a stove with iron pipe for chimney, from which fumes of combustion must leak when in use, and a fan which would not work. When the men are shut down the moisture is such that boots, \&c., go mouldy and the water drips off the structure. The cooling effect of the sea-water washing over the steel shell of the boat is beneficial in keeping down the temperature in these confined and ill-ventilated quarters. On the manœuvring platform in the engineroom the wet-bulb temperature reaches a very high degree owing to the slight escape of steam round the turbines. Commander Domvile was kind enough to send me the wet and dry bulb temperatures taken there on a number of days. The wet bulb was found to be never below $80^{\circ} \mathrm{F}$., sometimes reaching $95^{\circ}$ and even $98^{\circ} \mathrm{F}$. It is impossible for officers to work at these temperatures without straining the heatregulating mechanism of the body and diminishing their health and working capacity. If such wet-bulb temperatures are unavoidable, means should be provided, such as fans, which would alleviate the discomfort and fatigue caused thereby. A supply of compressed air fitted with a nozzle might be arranged and used occasionally to douche the body with cool air. I have tried this plan and found it very effectual NO. 2240 , VOL. 90] 
and can recommend the compressed-air bath as the substitute for a bracing cold wind.

The suitability of the clothing is of the greatest importance, not only to the comfort but to the efficiency of man as a working machine, e.g. power of soldiers to march. On a still day the body is confined by the clothes as if by a chamber of stagnant air, for the air is enclosed in the meshes of the clothes and the layer in contact with the skin becomes heated to body temperature and saturated with moisture.

The observations of Pembrey show that himself and four soldiers, marching in drill order on a moderately warm day, lost more water and retained more water in their clothes than on another similar day when they worked with no jacket on. The average figures were loss of moisture 1600 , against 1200 grms., and water retained in clothes 254 against 109 grms. With no jacket the pulse was, on the average, increased 28 against $4 \mathrm{I}$ in drill order, and rectal temperature $x^{\circ}$ against $I^{\circ} 5^{\circ} \mathrm{F}$. The taking off of the jacket or throwing open of the jacket and vest very greatly increase the physiological economy of a march. It is absurd that on a hot summer day Boy Scouts should march with coloured scarves knotted round their necks. Nothing should be worn for ornament or smartness which increases the difficulty of keeping down the body temperature. The power to march and the efficiency of an army depend on prevention of heart stagnation and avoidance of fatigue of the heart.

I conclude, then, that all the efforts of the heating and ventilating engineer should be directed towards cooling the air in crowded places and cooling the bodies of the people by setting the air in motion by means of fans. In a crowded room the air confined between the bodies and clothes of the people is almost warmed up to body temperature and saturated with moisture, so that cooling of the body by radiation, convection and evaporation becomes reduced to a minimum. The strain on the heat-regulating mechanism tells on the heart. The pulse is accelerated, the blood is sent in increased volume to the skin, and circulates there in far greater volume, while less goes through the viscera and brain. As the surface temperature rises, the cutaneous vessels dilate, the veins become filled, the arteries may become small in volume, and the blood-pressure low, the heart is fatigued by the extra work thrown upon it. The influence of the heat stagnation is shown by the great acceleration of the pulse when work is done, and the slower rate at which the pulse returns to its former rate on resting.

The increased percentage of carbonic acid and diminution of oxygen which has been found to exist in badly ventilated churches, schools, theatres, barracks, is such that it can have no effect upon the incidence of respiratory disease and higher deathrate which statistical evidence has shown to exist among persons living in crowded and unventilated rooms. The conditions of temperature, moisture, and windless atmosphere in such places primarily diminish the heat loss, and secondarily the heat production, i.e., the activity of the occupants, together with total volume of air breathed, oxygen taken in and food eaten. The whole metabolism of the body is thus run at a lower plane and the nervous system and tone of the body is unstimulated by the monotonous, warm, and motionless air. If hard work has to be done it is done under conditions of strain. The number of pathogenic organisms is increased in such places, and these two conditions run together-diminished immunity and increased mass influence of infecting bacteria.

The volume of blood passing through, and of water NO. 2240 , VOL. 90 vapour evaporated from, the respiratory mucous membrane must have a great influence on the mechanisms which protect this tract from bacterial infection. While too wet an atmosphere lessens evaporation, a hot dry atmosphere dries up the mucous membrane. As the immunising powers depend on the passage of blood plasma into the tissue spaces, it is clear that a proper degree of moisture is important. The temperature, too, must have a great influence on the scavenger activity of the ciliated epithelium and leucocytes in the mucous membrane of the nose.

In the warm moist atmosphere of a crowded place the infection from spray, sneezed, coughed, or spoken out, is enormous. On passing out from such an atmosphere into cold moist air the respiratory mucous membrane of the nose is suddenly chilled, the bloodvessels constricted, and the defensive mechanism of cilia and leucocyte checked. Hence the prevalence of colds in the winter. In the summer the infection is far less. We are far more exposed to moving air, and the sudden transition from a warm to a cold atmosphere does not occur. I believe that infection is largely determined by ( $\mathrm{r}$ ) the mass influence of the infecting agent; (2) the shallow breathing and diminished evaporation from, and flow of tissue lymph through, the respiratory tract, in warm, moist confined air. Colds are not caught by exposure to cold per se, as is shown by the experience of Arctic explorers, sailors, shipwrecked passengers, \&c.

We have very great inherent powers of withstanding exposure to cold. The bodily mechanisms become trained and set to maintain the body heat by habitual exposure to open-air life. The risk lies in overheating our dwellings and overclothing our bodies, so that the mechanisms engaged in resisting infection become enfeebled, and no longer able to meet the sudden transition from the warm atmosphere of our rooms to the chill outside air of winter. The dark and gloomy days of winter confine us within doors, and, by reducing our activity and exposure to open air, depress the metabolism; the influence of smoke and fog, gloom of house and streets, cavernous places of business and dark dwellings, intensify the depression. The immunity to a cold after an infection lasts but a short while, and when children return, after the summer holidays, to school and damp chill autumn days, infection runs around. The history of hospital gangrene and its abolition by the aseptic methods of Lister-likewise the history of insect-borne disease-show the great importance of cleanliness in crowded and much occupied rooms. The essentials required of any good system of ventilating are then (I) movement, coolness, proper degree of relative moisture of the air; $(2)$ reduction of the mass influence of pathogenic bacteria. The chemical purity of the air is of very minor importance, and will be adequately insured by attendance to the essentials.

As the prevention of spray (saliva) infection by ventilation is impossible in crowded places, it behoves us to maintain our immunity at a high level. We may seek to diminish the spray output of those infected with colds by teaching them to cough, sneeze, and talk with a handkerchief held in front of the mouth, or to stay at home until the acute stage is past.

In all these matters nurture is of the greatest importance, as well as nature. A man is born with physical and mental capacities small or great, with inherited characteristics, with more or less immunity to certain diseases, with a tendency to longevity of life or the opposite, but his comfort and happiness in life, the small or full development of his physical and mental capacities, his immunity and his longevity of life, are undoubtedly determined to a vast extent by nurture. 
By nurture-I use the word in its widest sense to include all the defensive methods of sanitary scienceplague, yellow fever, malaria, sleeping-sickness, cholera, hospital gangrene, \&c., can be prevented by eliminating the infecting cause; smallpox and typhoid by this means, and also by vaccination; and most of the other ills which flesh is supposed to be heir to can be kept from troubling by approximating to the rules of life which a wild animal has to follow in the matter of a simple, and often spare diet, hard exercise, and exposure to the open air.

There is nothing more fallacious than the supposition commonly held that over-feeding and overcoddling indoors promotes health. The two together derange the natural functions of the body. He who seeks to save his life will lose it.

The body of a new-born babe is a glorious and perfect machine, the heritage of millions of years of evolution.

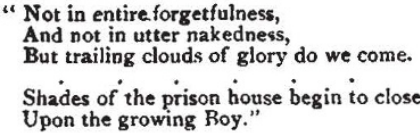

The ill-conditioned body, anæmic complexion and undersized muscles, or the fat and gross habit, the decay of the teeth, the disordered digestion, the nervous irritability and unhappiness are the result of "Nurture" - not Nature.

In institutions children may be disciplined to vigorous health. After leaving school they are set adrift to face monotonous work in confined places, amusement in music-halls and cinema shows in place of manly exercise in the open air, injudicious diet, alcohol, and tobacco-everything which the trainer of an athlete would repel.

"And custom lie upon him with a weight
Heavy as frost, and deep almost as life."

\section{UNIVERSITY AND EDUCATIONAL INTELLIGENCE.}

SHEFFIELD. - The council of the University of Sheffield has made the following appointments:-(r) Dr. H. R. Dean, to the Joseph Hunter chair of pathology, in succession to Prof. J. M. Beattie, who has been appointed to the chair of bacteriology in the University of Liverpool. Dr. Dean is at present assistant bacteriologist to the Lister Institute of Preventive Medicine. (2) Mr. Leonard Southerns, to the post of junior lecturer and demonstrator in physics, vice Dr. J. Robinson, resigned. Mr. Southerns is at present chief assistant at the Eskdalemuir Observatory, N.B. The council received the resignation of Prof. F. W. Hardwick of the professorship of mining, owing to his retirement from active work. Prof. Hardwick has been on the staff since October, 1891 .

A coURSE of fifteen lectures on Indian sociology will be delivered at East London College (University of London), Mile End Road, E., by Mr. T. C. Hodson (late of the Indian Civil Service), on Wednesdays at 5.30, commencing October 23. The lectures are open to the public without fee.

Dr. A. N. WhItehead, F.R.S., University reader in geometry, will deliver at University College, London, a non-technical course of lectures on "The General Ideas of the Science of Geometry" during the first two terms of the session. The course will begin on Tuesday, October 8 , at 5 p.m.

THE opening of the session at Edinburgh University will see the inauguration of the new scheme for engineering degrees by which the full resources of the University and the Heriot-Watt College are NO. 2240 , VOL. 90] utilised for the first time to enable students to specialise in the three departments of civil, mechanical, and electrical engineering.

A Reuter message from Cape Town states that in view of the fact that there is no precedent for the Sovereign's holding office in any university of the Empire, the King has resigned the Chancellorship of the Cape University with which his Majesty was invested on the occasion of his visit to South Africa in xgor as Duke of Cornwall. The Duke of Connaught has accepted nomination to the Chancellorship in succession to the King.

ANNOUNCEMENT is made of two courses of postgraduate lectures to be delivered at University College (University of London), by Prof. J. A. Fleming, F.R.S. (Pender professor of electrical engineering). One course, on "Electromagnetic Waves and the Theory of Electrons," will be delivered on Wednesdays at 5 p.m., beginning Wednesday, November 6, and the other, on "Electric Wave Wireless Telegraphy," will begin on Wednesday, January 22, 1913.

At the University of Bristol, the calendar of which for the session $1912-13$ has been received, the bachelor's degree can be taken in engineering, both by day and evening students. The final part of the curriculum may be in civil, mechanical, electrical, or motor-car engineering. At Bristol also, it is interesting to note, the Senate of the University is authorised to confer a testamur in social study and in journalism -a further indication of the desire of the modern university to assist directly every kind of professional work.

THE best criterion of the vitality of a university is the record of its members' contributions to knowledge. The magnitude of such a list cannot, of course, be taken as a measure of the importance of the original work accomplished, but it indicates the activity of the various departments of the university to which the list refers, and shows that attention is not being concentrated unduly upon examination standards. A list of memoirs, papers, \&c., published during the years $1909-1912$ by members of the teaching staff, scholars and fellows, research students, and others connected with the University of Glasgow has just been received, and it provides convincing evidence of the large amount of literary and scientific work published by members of the University. The uniform distribution of these products through all departments should be a particular cause of gratification to the principal.

THE needs of students of anolied science receive increasing attention year by year from university authorities in different parts of the country. The new calendar of Armstrong College, Newcastle-upon-Tyne, one of the constituent colleges of the University of Durham, shows that here, for example, students, in addition to being able to obtain the degree of bachelor of science in pure science, may, if they prefer, offer instead one of seven branches of applied science. Degrees may, in fact, be obtained in agriculture, mechanical and marine engineering, electrical engineering, civil engineering, naval architecture, mining, or metallurgy. The calendar shows, too, that the active cooperation of engineering and shipbuilding firms in the district has been secured. Many manufacturers have promised to cooperate with the college by receiving pupils in the several departments of their works and in their drawing offices, and by permitting them to devote themselves exclusively during two or three sessions to their college studies.

THE prospectus for the session I9I2-I3 of the day and evening college for men and women at the SouthWestern Polvtechnic, Chelsea, serves excellently to 